\title{
Pengaruh Motivasi Ekstrinsik terhadap Perilaku Menyikat Gigi pada Anak
}

\author{
Melyana Wanti, Christy N. Mintjelungan, Vonny N. S. Wowor
}

\author{
Program Studi Pendidikan Dokter Gigi Fakultas Kedokteran Universitas Sam Ratulangi, \\ Manado, Sulawesi Utara, Indonesia \\ Email: 16011103016@ student.unsrat.ac.id
}

\begin{abstract}
Dental caries is a dental health problem that often affects children aged 6-12 years. Children who have bad habits in maintaining oral hygiene are at greater risk to suffer from dental caries. A good habit that can be developed to obtain a good behavior is tooth brushing. The behavior of tooth brushing in children can be influenced by many things, inter alia intrimsic or extrinsic motivation. This study was aimed to determine whether there was an extrinsic motivation on tooth brushing behavior among elementary school students. This was a literature review study using databases of Google Scholar, PubMed, ScienceDirect, and Indonesia Onesearch. There were five literatures with cross-sectional design used in this study. The results showed that extrinsic motivation could influence the tooth brushing behavior of the students. Parents and teachers had a major role in influencing the students for tooth brushing behavior. In conclusion, there is an influence of extrinsic motivation on children's tooth brushing behavior.
\end{abstract}

Keywords: motivation, behavior, tooth brushing, children

\begin{abstract}
Abstrak: Karies gigi merupakan masalah gigi yang sering menyerang anak usia 6-12 tahun. Anak yang memiliki kebiasaan buruk dalam pemeliharaan kebersihan gigi dan mulutnya berisiko lebih besar terkena karies gigi. Kebiasaan baik yang dapat dikembangkan untuk menghasilkan perilaku yang baik, yakni kebiasaan menyikat gigi. Perilaku menyikat gigi pada anak dapat dipengaruhi oleh banyak hal, salah satunya ialah motivasi yang dapat berasal dari dalam (intrinsik) maupun dari luar diri seseorang (ekstrinsik). Penelitian ini bertujuan untuk mengetahui adanya pengaruh motivasi ekstrinsik terhadap perilaku menyikat gigi siswa sekolah dasar. Jenis penelitian ialah literature review dengan menggunakan empat database yaitu Google Scholar, PubMed, ScienceDirect, dan Indonesia Onesearch. Lima literatur yang diperoleh dalam penelitian ini menggunakan desain potong lintang. Hasil penelitian memperlihatkan motivasi ekstrinsik berpengaruh terhadap perilaku menyikat gigi anak. Orang tua dan guru memiliki peran utama dalam memengaruhi motivasi menyikat gigi anak. Simpulan penelitian ini ialah terdapat pengaruh motivasi ekstrinsik terhadap perilaku menyikat gigi anak.
\end{abstract}

Kata kunci: motivasi, perilaku, menyikat gigi, anak

\section{PENDAHULUAN}

Gigi merupakan salah satu organ tubuh dalam mulut yang terlibat dalam proses pencernaan. Gigi memiliki beberapa fungsi, salah satunya berfungsi dalam pengunyahan makanan sehingga makanan lebih mudah untuk dicerna. Saat proses pengunyahan sisa makanan dapat mengendap dan terakumulasi di mulut; kondisi ini menyebabkan peningkatan pertumbuhan bakteri penyebab masalah gigi. Salah satu masalah yang ditimbulkan yaitu gigi berlubang atau karies gigi yang dapat berdampak pada kesehatan tubuh secara keseluruhan. ${ }^{1}$

Laporan Nasional Riskesdas Tahun 2018 menyatakan bahwa persentase yang mengalami masalah gigi berlubang, rusak atau sakit di Indonesia berdasarkan kelompok usia 5-9 tahun sebesar 54,0 \% dan usia 10-14 tahun sebesar $41,4 \% .^{2}$ Data tersebut memperlihatkan bahwa kerusakan gigi anak usia sekolah masih terbilang tinggi. Angka 
prevalensi tertinggi terhadap kerusakan gigi terdapat di Provinsi Sulawesi Tengah 60,4\% diikuti Maluku 56,3\%, Sulawesi Barat $56,2 \%$, serta Sulawesi Selatan dan Sulawesi Utara 55,5 \%. Pulau Sulawesi memiliki nilai tertinggi kerusakan gigi dengan prevalensi tertinggi dipegang oleh Provinsi Sulawesi Tengah $60,4 \% .^{2}$

Karies gigi sering menyerang anak usia 6-14 tahun yang merupakan kelompok usia kritis dan mempunyai sifat khusus yaitu transisi/pergantian dari gigi susu ke gigi permanen. ${ }^{3}$ Laporan dari Persatuan Dokter Gigi Indonesia (PDGI) menyebutkan bahwa sebanyak $89 \%$ penderita karies ialah anakanak. ${ }^{4}$ Penyakit ini tidak menyebabkan kematian, namun jika diabaikan dapat berdampak pada kesehatan dan kualitas hidup anak tersebut secara keseluruhan. Karies gigi erat kaitannya dengan kebersihan gigi mulut; hal ini didukung dengan penelitian yang dilakukan Huda dan Zulkifri ${ }^{5}$ yang menyatakan adanya hubungan kebersihan gigi dan mulut dengan indeks karies gigi pada murid SDN 03 Pakan Kurai, Kecamatan Guguk Panjang, Kota Bukittinggi. Anak yang memiliki kebiasaan buruk dalam pemeliharaan kebersihan gigi mulutnya, berisiko besar terkena karies gigi dan penyakit periodontal.

Kebiasaan buruk yang terus menerus dilakukan akan berkembang menjadi perilaku. Demikian pula sebaliknya dengan kebiasaan yang baik. Salah satu kebiasaan baik yang dapat dikembangkan untuk menghasilkan suatu perilaku yang baik, yakni kebiasaan menyikat gigi. Menyikat gigi merupakan cara sederhana dan paling mudah diajarkan dan dilakukan untuk menjaga kebersihan gigi mulut anak.

Perilaku menyikat gigi anak sekolah dasar dapat dipengaruhi oleh banyak hal, salah satunya motivasi. Motivasi merupakan sesuatu yang mendorong seseorang untuk bertindak, dapat berupa motivasi yang berasal dari dalam (motivasi intrinsik) maupun dari luar diri seseorang (motivasi ekstrinsik). Motivasi intrinsik antara lain berupa kebutuhan dan minat, sementara motivasi ekstrinsik dapat berupa dorongan keluarga, lingkungan, dan fasilitas yang ada.
Penelitian yang dilakukan Dewi ${ }^{6}$ memperlihatkan adanya hubungan yang cukup erat antara motivasi anak dengan perilaku menyikat gigi anak usia sekolah di SDN Panti 01 Kecamatan Panti Kabupaten Jember. Adanya dukungan motivasi akan turut memengaruhi pembentukan perilaku positif anak dalam memelihara kesehatan gigi mulut.

Berdasarkan latar belakang yang telah dipaparkan, penulis terdorong untuk meneliti pengaruh motivasi ekstrinsik terhadap perilaku menyikat gigi pada anak yang mendasari anak dalam pemeliharaan kesehatan gigi dan mulut melalui studi pustaka.

\section{METODE PENELITIAN}

Penelitian ini merupakan suatu penelitian kualitatif dalam bentuk literature review yang dilakukan pada bulan September 2020-Januari 2021. Sumber data yang digunakan diperoleh dari empat database yaitu Google Scholar, PubMed, Science Direct dan Indonesia Onesearch. Pencarian data menggunakan beberapa kata kunci yakni dalam bahasa Indonesia, yaitu motivasi DAN perilaku DAN menyikat gigi ATAU menggosok gigi DAN anak, sedangkan kata kunci dalam bahasa Inggris, yaitu motivation AND behavior AND tooth brushing OR brushing teeth AND children.

Sumber data dibatasi dengan menggunakan kriteria inklusi dan ekslusi. Kriteria inklusi, yaitu artikel terbitan 10 tahun terakhir baik dalam bahasa Indonesia maupun Inggris dengan sampel penelitian berada pada usia 6-12 tahun. Kriteria ekslusi, yaitu literatur tidak relevan dengan judul penelitian dan tidak tersedia format fulltext maupun jurnal yang dipublikasikan.

\section{HASIL PENELITIAN}

Jumlah literatur yang diperoleh dari empat database yang digunakan yaitu 453 dari Google Scholar, 55 dari PubMed, 636 dari ScienceDirect dan 6 dari Indonesia Onesearch $(\mathrm{n}=1150)$. Hasil pencarian disaring berdasarkan judul dan abstrak yang sesuai dengan topik bahasan. Literatur yang sama dan terdapat di database yang berbeda hanya dihitung sebagai satu literatur, hingga 
didapatkan sebanyak 24 literatur. Selanjutnya, literatur disaring berdasarkan kriteria inklusi dan eksklusi, dan diperoleh lima literatur yang dipilih menjadi sumber data dalam penelitian ini. Kelima literatur ini menggunakan desain potomg lintang. Tabel 1 memperlihatkan hasil kajian literatur yang digunakan dalam penelitian.

Tabel 1. Hasil kajian literatur yang digunakan dalam penelitian

\begin{tabular}{|c|c|c|c|c|}
\hline $\begin{array}{c}\text { Peneliti/ } \\
\text { Tahun }\end{array}$ & Judul & Populasi & $\begin{array}{c}\text { Study Design \& } \\
\text { Sumber Data }\end{array}$ & Hasil \\
\hline $\begin{array}{l}\text { Factarun, } \\
2017^{7}\end{array}$ & $\begin{array}{l}\text { Hubungan } \\
\text { motivasi dan } \\
\text { perilaku meng- } \\
\text { gosok gigi } \\
\text { dengan karies } \\
\text { gigi pada anak } \\
\text { usia sekolah di } \\
\text { MI NU Islah- } \\
\text { ussalafiyah } \\
\text { Kudus }\end{array}$ & $\begin{array}{l}\text { Populasi: } 86 \\
\text { Sampel: } 46 \\
\text { Kelas: } 4 \text { \& } 5 \\
\text { Usia: } 9-11 \\
\text { Random } \\
\text { sampling }\end{array}$ & $\begin{array}{l}\text { Cross sectional, } \\
\text { pengambilan data } \\
\text { dengan kuesioner } \\
\text { dan observasi }\end{array}$ & $\begin{array}{l}30 \text { anak yang mempunyai } \\
\text { motivasi tinggi sebagian } \\
\text { besar anak tidak mengalami } \\
\text { karies gigi }(96,7 \%), 16 \text { anak } \\
\text { yang mempunyai motivasi } \\
\text { rendah sebagian besar } \\
\text { mengalami karies gigi } \\
(68,8 \%) .\end{array}$ \\
\hline $\begin{array}{l}\text { Arianto et al, } \\
2014^{8}\end{array}$ & $\begin{array}{l}\text { Perilaku meng- } \\
\text { gosok gigi pada } \\
\text { siswa Sekolah } \\
\text { Dasar Kelas V } \\
\text { dan VI di Keca- } \\
\text { matan Sumberejo }\end{array}$ & $\begin{array}{l}\text { Populasi: } 986 \\
\text { Sampel: } 285 \\
\text { Kelas: } 5 \text { \& } 6 \\
\text { Usia: } 10-12 \\
\text { Proportional } \\
\text { random } \\
\text { sampling }\end{array}$ & $\begin{array}{l}\text { Cross sectional, } \\
\text { pengambilan data } \\
\text { dari wawancara } \\
\text { dan kuesioner }\end{array}$ & $\begin{array}{l}\text { Hasil signifikan yang } \\
\text { berpengaruh terhadap } \\
\text { perilaku menyikat gigi anak } \\
\text { yaitu orang tua dan guru. } \\
\text { Hasil uji memperlihatkan } \\
\text { Peran orang tua dan guru yg } \\
\text { baik mempunyai } \\
\text { kemungkinan anak } \\
\text { berperilaku baik sebanyak } 2 \\
\text { kali lebih besar. }\end{array}$ \\
\hline $\begin{array}{l}\text { Angelopoulou et } \\
\text { al, } 2015^{9}\end{array}$ & $\begin{array}{l}\text { Oral hygiene } \\
\text { facilitators and } \\
\text { barriers in Greek } \\
10 \text { years old } \\
\text { school-children }\end{array}$ & $\begin{array}{l}\text { Sampel: } 266 \\
\text { Kelas: } 4 \\
\text { Usia: } 10 \text { (laki- } \\
\text { laki } 142 \& \\
\text { perempuan } 124 \text { ) } \\
\text { Total sampling }\end{array}$ & $\begin{array}{l}\text { Cross sectional, } \\
\text { pengambilan data } \\
\text { dari kuesioner dan } \\
\text { pemeriksaan klinis }\end{array}$ & $\begin{array}{l}\text { Motif utama anak menyikat } \\
\text { gigi yaitu estetika }(62,28 \%) \text {. } \\
\text { Frekuensi menyikat gigi, } \\
\text { pendidikan \& pendampingan } \\
\text { orang tua berkorelasi positif } \\
\text { terhadap perilaku menyikat } \\
\text { gigi anak. }\end{array}$ \\
\hline $\begin{array}{l}\text { Davison et al, } \\
2019^{10}\end{array}$ & $\begin{array}{l}\text { Factors influen- } \\
\text { cing children's } \\
\text { tooth brushing } \\
\text { intention: an } \\
\text { application of the } \\
\text { theory of planned } \\
\text { behaviour }\end{array}$ & $\begin{array}{l}\text { Sampel: } 867 \\
\text { Kelas: } 6 \\
\text { Usia: } 9-10 \\
\text { (laki-laki } 442 \\
\text { \& perempuan } \\
\text { 425) } \\
\text { Stratified } \\
\text { random } \\
\text { sampling }\end{array}$ & $\begin{array}{l}\text { Cross sectional, } \\
\text { pengambilan data } \\
\text { dengan kuesioner }\end{array}$ & $\begin{array}{l}\text { Motif utama anak menyikat } \\
\text { gigi ialah efikasi diri. Niat } \\
\text { menyikat gigi dipengaruhi } \\
\text { juga sikap menyikat gigi, } \\
\text { norma subjektif \& kontrol } \\
\text { yang dirasakan. }\end{array}$ \\
\hline $\begin{array}{l}\text { Firdausiyah et al, } \\
2016^{11}\end{array}$ & $\begin{array}{l}\text { Pengaruh pen- } \\
\text { dampingan orang } \\
\text { tua terhadap } \\
\text { motivasi anak } \\
\text { untuk menyikat } \\
\text { gigi di SDN } \\
\text { Tinjomayo } 02 \\
\text { Semarang }\end{array}$ & $\begin{array}{l}\text { Sampel: } 18 \\
\text { siswa dan } 9 \\
\text { orang tua Kelas: } \\
1 \\
\text { Usia: } 6-7 \\
\text { Purposive } \\
\text { sampling }\end{array}$ & $\begin{array}{l}\text { Cross sectional, } \\
\text { pengambilan data } \\
\text { dari hasil } \\
\text { observasi }\end{array}$ & $\begin{array}{l}\text { Kelompok pendampingan } \\
\text { dengan tingkat motivasi } \\
\text { anak untuk menyikat gigi } \\
\text { sebesar } 44 \% \text { dalam kriteria } \\
\text { kuat dan kelompok tanpa } \\
\text { pendampingan orang tua } \\
\text { dengan tingkat motivasi } \\
\text { anak untuk menyikat gigi } \\
\text { sebesar } 22 \% \text { dalam kriteria } \\
\text { lemah. }\end{array}$ \\
\hline
\end{tabular}




\section{BAHASAN}

Motivasi dapat memengaruhi perilaku menyikat gigi anak dimana anak yang memiliki motivasi baik cenderung memiliki perilaku menyikat gigi lebih baik, sebaliknya anak yang memiliki motivasi rendah cenderung memiliki perilaku menyikat gigi yang kurang. Motivasi yang baik membantu perilaku menyikat anak menjadi lebih baik.

Penelitian yang dilakukan oleh Factarun $^{7}$ memperlihatkan bahwa pada anak yang mempunyai motivasi rendah, sebagian besar mengalami karies gigi sedangkan pada anak yang mempunyai motivasi tinggi sebagian besar tidak mengalami karies gigi. Karies gigi terjadi karena anak malas menyikat gigi dan waktu menyikat gigi yang tidak tepat sehingga kebersihan gigi mulut menjadi rendah dan terjadilah karies. Hal ini menunjukkan bahwa pada anak yang jarang memelihara kebersihan gigi dan mulutnya sebagian besar mempunyai motivasi rendah demikian pula sebaliknya.

Factarun ${ }^{7}$ juga menjelaskan bahwa anak tidak termotivasi karena orang tua tidak memberikan pemahaman atau mengingatkan anak untuk menyikat gigi, serta tidak menegur jika anak tidak menyikat gigi. Motivasi menyikat gigi yang rendah dari orang tua berbanding lurus dengan motivasi menyikat gigi anak yang rendah sehingga anak malas atau tidak terbiasa menyikat gigi. Motivasi anak rendah karena tidak termotivasi; hal ini dapat disebabkan karena anak tidak mengetahui alasan penting untuk menyikat gigi. Hal ini didukung oleh teori Mulyasa $^{12}$ yang menyebutkan bahwa prinsip yang dapat diterapkan untuk meningkatkan motivasi salah satunya ialah dengan menjelaskan dan menginformasikan secara jelas tujuan yang ingin dicapai. Perilaku anak dalam menyikat gigi akan lebih mudah dan efektif apabila anak tersebut tahu manfaat menyikat gigi, tahu cara yang benar dalam menyikat gigi serta tahu akibat dan dampak jika tidak rutin menyikat gigi.

Penelitian yang dilakukan oleh Arianto et $\mathrm{al}^{8}$ memperlihatkan pengaruh orang tua dan guru terhadap perilaku menyikat gigi anak. Hasil penelitian ini menunjukkan bahwa perilaku menyikat gigi yang kurang terdapat lebih banyak pada kelompok siswa sekolah dasar (SD) dengan sikap dan perilaku orang tua/gurunya kurang dibandingkan dengan siswa SD yang sikap dan perilaku orang tua/gurunya baik. Hasil uji analisis memperlihatkan peran orang tua dan guru yang baik mempunyai kemungkinan anak berperilaku menyikat gigi yang baik sebanyak 2 kali lebih besar dibandingkan dengan peran orang tua dan guru yang kurang. Penelitian oleh Arianto et $\mathrm{al}^{8}$ menunjukkan bahwa peran orang tua dan guru dalam menyampaikan informasi, memotivasi, menyediakan sarana dan prasarana, serta menjadi panutan dalam kebiasaan menyikat gigi memengaruhi perilaku menyikat gigi anak. Peran orang tua dan guru yang kurang akan berkorelasi dengan perilaku menyikat gigi anak yang kurang. Peran orang tua dan guru dalam mendukung dan mendorong anak untuk menyikat gigi sangat penting dalam peningkatan perilaku positif menyikat gigi anak.

Orang tua dan guru dapat meningkatkan perilaku menyikat gigi anak menjadi lebih baik dengan selalu berusaha memberikan informasi kepada anak mengenai pentingnya kebiasaan menyikat gigi. Selain itu orang tua dan guru dapat menjadi motivator dengan memberikan motivasi atau mendorong anak untuk bertindak. Orang tua dan guru dapat meningkatkan motivasi menyikat gigi anak dengan selalu mengajak anak untuk menyikat gigi, menyediakan alat dan keperluan yang dibutuhkan untuk menunjang aktivitas menyikat gigi. Hal ini didukung oleh penelitian yang dilakukan oleh Suhono dan Utama ${ }^{13}$ yang menjelaskan keteladanan orang tua dan guru sangat penting diperhatikan dalam membimbing dan mendidik anak karena merupakan bagian integral dalam proses pendidikan dengan tujuan untuk membekali anak dalam memecahkan berbagai masalah kehidupan. Orang tua dan guru memiliki peran utama dalam mengajar dan membentuk kebiasaan pada anak.

Penelitian Angelopoulou et $\mathrm{al}^{9}$ menyatakan bahwa sebagian besar anak yang memiliki pengetahuan menyikat gigi yang baik akan cenderung lebih sering menyikat 
gigi dan disertai juga aktivitas menyikat gigi orang tuanya dalam kategori baik. Pengetahuan anak yang baik berkorelasi dengan pengetahuan orang tua yang baik tentang perawatan kesehatan gigi mulut. ${ }^{9}$ Anakanak yang orang tuanya terlibat selama kegiatan menyikat gigi lebih sering menggunakan benang gigi, hal ini diperlihatkan pada anak-anak yang mempraktikkan penggunaan flossing berkorelasi positif dengan pengawasan dan dorongan orang tua. Orang tua yang memiliki pengetahuan baik akan lebih sering mendorong anaknya untuk ikut melakukan flossing bersama.

Davison et $\mathrm{al}^{10}$ mengemukakan bahwa persepsi anak tentang pendapat dan dorongan orang tua, keluarga, dan teman berkorelasi dengan niat menyikat gigi anak. Orang tua khususnya ayah sangat menonjol dalam penelitian ini, di mana ayah paling sering mendorong anak menyikat gigi dan hal ini menjadi alasan anak menyikat gigi. Meskipun ayah sebagai rujukan paling populer untuk niat menyikat gigi anak namun ibu dan teman dekat juga berpengaruh. Hal ini didukung oleh penelitian yang dilakukan Andriyani ${ }^{14}$ yang menyatakan bahwa orang tua mempunyai peran sangat penting dalam memelihara kesehatan gigi anak, misalnya memberi contoh perawatan gigi, memotivasi merawat gigi, mengawasi perawatan gigi, dan membawa anak ke dokter gigi.

Firdausiyah et $\mathrm{al}^{11}$ menyatakan bahwa pendampingan yang dilakukan orang tua dapat mengubah perilaku anak. Kelompok anak yang didampingi oleh orang tua memiliki tingkat motivasi yang lebih tinggi dibandingkan kelompok anak tanpa pendampingan. ${ }^{9}$ Hal ini menunjukkan bahwa anak-anak memperhatikan perilaku orang tuanya; dengan kata lain orang tua menjadi sumber pengetahuan yang memengaruhi motivasi menyikat gigi anak sehingga dapat disimpulkan bahwa pendampingan orang tua cenderung lebih baik terhadap motivasi anak untuk menyikat gigi. Hal ini juga selaras dengan teori yang dikemukakan Green tentang perubahan perilaku, yaitu bahwa salah satu faktor yang memengaruhi perilaku seseorang ialah faktor penguat (reinforcing factor) yang mencakup du- kungan sosial dan pengaruh teman sebaya yang akan memperkuat perilaku. ${ }^{8}$

Dengan demikian dapat disimpulkan bahwa motivasi ekstrinsik memengaruhi perilaku menyikat gigi pada anak. Orang tua dan guru berperan utama dalam memengaruhi motivasi menyikat gigi anak. Semakin tinggi motivasi menyikat gigi pada anak maka perilaku menyikat gigi anak juga akan semakin baik dan sebaliknya.

Keterbatasan penelitian ini ialah literatur yang digunakan masih sangat kurang. Selain itu, literatur yang digunakan dalam penelitian ini tidak memiliki tujuan penelitian yang sama dan cara pengambilan data menggunakan kuesioner yang berbeda. Dengan demikian motivasi dan perilaku dapat dipengaruhi oleh faktor-faktor yang berbeda pula.

\section{SIMPULAN}

Terdapat pengaruh motivasi ekstrinsik terhadap perilaku menyikat gigi anak.

\section{Konflik Kepentingan}

Penulis menyatakan tidak terdapat konflik kepentingan dalam studi ini.

\section{DAFTAR PUSTAKA}

1. Kidd E, Fejerskov O, editors. Dental caries, The Disease and its Clinical Management. Tunbridge Wells, Kent: Blackwell Munksgaard, 2008; p. 4-5.

2. Lab Data Litbang Depkes. Laporan Nasional Riskesdas 2018 [monograph online]. Jakarta: Kemenkes RI [cited 2020 Feb 21]. p. 184-5. Available from: https:// archive.org/details/LaporanRiskesdas2 018NasionalPromkes.net/mode/1up.

3. Pay MN, Widiati S, Sriyono N. Faktor-faktor yang memengaruhi perilaku anak dalam pemeliharaan kebersihan gigi dan mulut. Majalah Kedokteran Gigi Indonesia. [cited 2020 May 23]. 2016; 2(1):26. Available from: https://jurnal. ugm.ac.id/ mkgi/article/view/9900/11421.

4. Norfai N, Rahman E. Hubungan pengetahuan dan kebiasaan menggosok gigi dengan kejadian karies gigi di SDI Darul Mu'minin Kota Banjarmasin tahun 2017. Dinamika Kesehatan. 2017;8(1): 213. Available from: https://scholar. google.com/citations?user=J18n2XYA 
AAAJ\&hl=id.

5. Huda ZI, Zulfikri. Hubungan indeks kebersihan gigi dan mulut dengan indeks karies gigi pada murid SDN 03 Pakan Kurai Kecamatan Guguk Panjang Kota Bukit tinggi. Jurnal Kesehatan Gigi. 2017; 4(1):59-60. Available from: http:// ejournal.poltekkes-smg.ac.id/ojs/index. php/jkg/article/view/2716/497.

6. Dewi PF. Hubungan motivasi anak dengan perilaku menyikat gigi anak usia sekolah di SDN Panti 01 Kecamatan Panti Kabupaten Jember 2017 [Skripsi]. Jember: Program Studi Ilmu Keperawatan Universitas Jember; 2017.

7. Factarun S. Hubungan motivasi dan perilaku menggosok gigi dengan karies gigi pada anak usia sekolah di MI NU Islahussalafiyah Kudus. Prosiding Hefa. 2018; 2:191-7. Available from: http:// prosiding.stikescendekiautamakudus.ac .id/index.php/pros/article/view/309/0.

8. Arianto, Shaluhiyah Z, Nugraha P. Perilaku menggosok gigi pada siswa sekolah dasar kelas V dan VI di Kecamatan Sumberejo. Jurnal Promosi Kesehatan Indonesia. 2014;9(2):127-35. Available from: https://ejournal.undip.ac.id/index. php/jpki/article/view/12728.

9. Angelopoulou M, Kavvadia K, Oulis C, Reppa C. Oral hygiene facilitators and barriers in Greek 10 Years Old schoolchildren. Int J Clin Pediatr Dent. 2015;8(2):87-93. Available from: https://www.ncbi.nlm. nih.gov/pmc/articles/PMC4562038/.
10. Davison J, McLaughlin M, Giles M. Factors influencing children's tooth brushing intention: an application of the theory of planned behaviour. Health Psychology Bulletin. 2019;3(1):58-66. Available from: https://www.healthpsychology bulletin.com/articles/10.5334/hpb.8/.

11. Firdausiyah EN, Siregar IH, Salikun. Pengaruh pendampingan orang tua terhadap motivasi anak untuk menyikat gigi di SDN Tinjomayo 02 Semarang. Repository Poltekes Kemenkes Semarang [serial online]. 2016 [cited 2020 Sep 8]. p. 5-1. Available from: http:// repository.poltekkes-smg.ac.id//index. php? $\mathrm{p}=$ show_detail\&id=14107.

12. Mulyasa E. Kurikulum Berbasis Kompetensi (Konsep, Karakteristik, Implementasi dan Inovasi). Bandung: PT. Remaja Rosdakarya, 2005; p. 114-5.

13. Suhono, Utama F. Keteladanan orang tua dan guru dalam pertumbuhan dan perkembangan anak usia dini. Elementary Jurnal Ilmiah Pendidikan Dasar. 2017; 3(2):107-19. Available from: https://ejournal.metrouniv.ac.id/index.php/elem entary/article/view/833/840.

14. Andriyani D. Hubungan peran orang tua dan guru dengan perilaku menyikat gigi murid di SDN 1 Perumnas Way Kandis Bandar Lampung. Jurnal Dunia Kesmas. 2014;3(1):45-39. Available from: http:// ejurnalmalahayati.ac.id/index.php/ duniakesmas/article/viewFile/386/321, 